\title{
Hubungan Pemberian Susu Formula Dengan Kejadian Diare Pada Bayi di Ruang Dahlia RSUD Dr. H. Soewondo Kendal
}

\section{The Relationship Of Formula Feeding With The Incidence Of Diarhhea In Infants In Dahlia Room RSUD Dr. H. Soewondo Kendal}

Tri Sakti Widyaningsih, Dwi Nur Aini, Ni Komang Ayu

\section{Intisari}

Latar belakang:. Diare adalah peningkatan jumlah, frekuensi, dan fluiditas (tingkat keenceran) feses. Diare dapat bersifat akut atau kronis. Diare kronis biasanya disebabkan oleh kondisi kronis seperti intoleransi laktosa. Pemberian susu formula terlalu dini dapat mempengaruhi kejadian diare pada bayi. Fenomena yang terjadi Di RSUD Dr.H.Soewondo Kendal banyak ibu bayi yang memberikan susu formula dan mengalami diare. Penelitian ini bertujuan untuk mengetahui hubungan pemberian susu formula dengan kejadian diare pada bayi.

Metode: Jenis penelitian adalah kuantitatif dengan pendekatan cross sectional dengan teknik pengambilan accidental sampling yang dilakukan pada 26 bayi yang diberi susu formula dan mengalami diare pada bulan Juli 2017. Pengumpulan data menggunakan kuesioner pemberian susu formula dengan kejadian diare.

Hasil penelitian: Hasil penelitian menunjukkan bahwa sebanyak 14 responden (53,8\%) dan pemberian susu formula tinggi sebanyak 12 responden (42,6\%) sedangkan responden dengan kejadian diare kronik 14 responden $(53,8 \%)$ dan kejadian diare akut 12 responden $(42,6 \%)$. Hasil uji statistik menggunakan uji chi square dengan $\alpha=0,05$ diperoleh hasil bahwa ada hubungan yang signifikan pemberian susu formula dengan kejadian diare di Ruang Dahlia RSUD Dr. H. Soewondo Kendal ( $p$-value=0,045) dengan nilai $X^{2}=4,013$.

Kesimpulan: Ada hubungan yang signifikan pemberian susu formula dengan kejadian diare di Ruang Dahlia RSUD Dr. H. Soewondo Kendal.

Saran: Diharapkan sebagai seorang ibu, bayi usia 0-6 bulan di Ruang Dahlia RSUD Dr.H. Soewondo Kendal memberikan ASI eksklusif tanpa pemberian makanan pendamping ASI lainnya.

Kata kunci: Diare, susu formula, Bayi.

Afiliasi Penulis
Prodi Ners STIKES Widya Husada Semarang

Korespondensi kepada

T.S. Widyaningsih

imoet.sakti@gmail.com 


\section{Abstract}

Background: Diarrhea is an increase in the number, frequency, and fluidity (level of dilution) of feces.Diarrhea can be acute and chronic. Chronic diarrhea is usually caused by chronic conditions, such as lactose intolerance. Early formula feeding can cause diarrhea in infants. Phenomena that occurred in Dahlia Room RSUD Dr. H. Soewondo Kendal is a lot of moms give formula milk to their baby and have diarrhea. This research aims to the relationship of formula feeding with diarrhea occurrence in infants.

Method: The type of research is quantitative with cross sectional approach with accidental sampling sampling technique conducted on 26 mother giving formula milk and diarrhea in Juli 2017. Data collection using formula feeding questionnaire with diarrhea occurrence.

Results: The results showed that 14 respondents $53.8 \%$ and high formula feeding were 12 respondent $(42,6 \%)$. Responden with chronic diarrhea cases were 14 respondent $(53,8 \%)$ and the incidence of acute diarrhea was 12 respondent (42,6\%). The result of statistical test using chi square test with $\alpha=0,05$ is found that relationship between formula feeding with diarrhea occurrence in Dahlia Room RSUD Dr. $\mathrm{H}$. Soewondo Kendal ( $p$ value $=0,045$ ) with value $X^{2}=4,013$.

Conclusion: There is a significant relationship between formula feeding and the incidence of diarrhea in the dahlia room RSUD Dr. H. Soewond Kendal.

Suggestion: Mother of a baby aged 0-6 months in Dahlia Room RSUD Dr. H. Soewondo Kendal, is expected to provide exclusive ASI without other complementary food.

Keywords: Diarrhea, Formula feeding, Infants.

\section{Pendahuluan}

Diare adalah peningkatan jumlah, frekuensi, dan fluiditas (tingkat keenceran) feses. Diare dapat bersifat akut atau kronis. Penyebab utama diare pada anak yang berusia kurang dari lima tahun adalah diare akut. Diare kronis adalah diare yang terjadi lebih dari dua minggu. Diare memiliki banyak peyebab yang berbeda. Diare yang menyebabkan dehidrasi akhirnya dapat menyebabkan syok hypopolemik dan dapat mengancam jiwa pada bayi dan anak. Diare berat sering terjadi pada bayi dan biasanya membutuhkan hospitalisasi (Axton dan Fugate, 2014:70).

World Health Organization (WHO) dan United Nations Children's Fund (UNICEF) menyatakan anak yang menderita diare berusia di bawah 5 tahun terutama di Negara berkembang sebanyak 1,9 juta dan merupakan salah satu penyebab kematian bayi dan balita terbesar di dunia. Kesehatan anak masih sangat rentan pada usianya di dua tahun pertama merupakan usia paling rentan terjangkit diare rotavirus dengan usia terbanyak rata rata 6-11 bulan (Prihaningtyas,2014:45).
Penyakit diare merupakan penyakit potensial Kejadian Luar Biasa (KLB) yang sering disertai dengan kematian. Menurut hasil Riskesdas 2007, diare merupakan penyebab kematian nomor satu pada bayi $(31,4 \%)$ dan pada balita $(25,2 \%)$, sedangkan pada golongan semua umur merupakan penyebab kematian yang ke-empat $(13,2 \%)$. Pada tahun 2012 angka kesakitan diare pada semua umur sebesar 214 per 1.000 penduduk dan angka kesakitan diare pada balita 900 per 1.000 penduduk (Kajian Morbiditas Diare 2012).

Proporsi kasus diare di Jawa Tengah tahun 2015 sebesar 67,7 persen, menurun bila dibandingkan proporsi tahun 2014 yaitu 79,8 persen. Hal ini menunjukkan penemuan dan pelaporan masih perlu ditingkatkan. Kasus yang ditemukan maupun yang diobati di layanan pemerintah maupun swasta belum semua terlaporkan.

Menurut Sutomo di dalam Kalay (2012), susu formula merupakan susu buatan pabrik yang telah diformulasikan menyerupai ASI, walaupun ASI tetap terbaik.Susu formula dibuat sesuai golongan usia bayi, mulai dari bayi yang baru lahir (new born ) usia 0-6 bulan, 6-12 bulan, dan usia batita 1-3 tahun, usia prasekolah 3-5 tahun,serta usia sekolah lima 
tahun ke atas. Diare sangat identik disebabkan oleh makanan dan minuman yang tidak bersih, basi, beracun, atau alergi terhadap makanan. Selain itu diare juga dapat disebabkan adanya gangguan penyerapan makanan, seperti karbohidrat (intoleransi laktosa), lemak, dan protein.

Wiliamsm seorang dokter spesialis anak perempuan pertama yang lulus di Inggris memberikan presentasi mengenai kematian bayi yang menggunakan susu formula dalam pertemuan Singapore Rotary Club dengan judul Milk and Murder. Beliau mengatakan bahwa propaganda terhadap pemberian susu bayi harus di hukum berat dan kematian -kematian bayi tersebut harus di anggap pembunuhan (IDAI,2011:101).

Klasifikasi diare menurut Prihaningtyas (2014), diklasifikasikan menjadi diare akut dan diare kronis. Diare akut jika terjadi kurang dari 14 hari (biasanya berlangsung selama 3-7 hari). Jika diare terjadi lebih dari 14 hari maka disebut dengan diare persisten. Diare persisten awalnya sebagai diare akut namun berakhir lebih dari 14 hari (Prihaningtyas, 2014:46).

Smith menyebutkan salah satu penyebab penting diare akut pada bayi dan anak yang bukan disebabkan oleh infeksi adalah enteropati karena sensitive terhadap protein susu sapi atau 'Cow's Milk Protein Sensitive Enteropathy (CMPSE)' atau lebih di kenal dengan alergi terhadap susu sapi atau 'Cow's Milk Alergy (CMA)'. CMA atau CMPSE dapat berupa diare akut, dan dapat juga menetap dan melanjut menjadi diare kronik (Suharyono, 2012:2).

Departemen Kesehatan memiliki istilah tersendiri untuk bayi (0-11 bulan), karena berkaitan dengan program pemerintah untuk bayi di tatanan pelayanan kesehatan dasar. Sementara Hockenberry dan Wilson menyebutkan usia 0-1 disebut fase bayi, 1-3 tahun disebut fase toddler (Purwanti dkk, 2014: 2).

\section{Metode}

Jenis penelitian ini adalah kuantitatif non eksperimental dengan metode penelitian deskriptif korelasional dengan menggunakan pendekatan cross sectional. Pendekatan cross sectional yaitu penelitian yang bertujuan untuk mengetahui hubungan antar variabel dimana variable dependen dan independen diidentifikasi pada satu satuan waktu. Teknik pengambilan sampel pada penelitian ini adalah acidental sampling. Sampel dalam penelitian ini adalah bayi yang dirawat $d$ ruang Dahlia yang diberikan susu formula dan mengalami diare. Sampel dalam penelitian ini sebanyak 26 bayi. Instrumen yang digunakan dalam penelitian ini adalah kuesioner dan tidak melakukan uji validitas data.

\section{Hasil}

Letak georafis Rumah Sakit Umum Daerah (RSUD) Dr. H. Soewondo Kendal merupakan Rumah Sakit kelas B milik Pemerintah Kabupaten Kendal yang terletak di Jalan Laut No 21 Kendal, Jawa Tengah, dengan kapasitas tempat tidur terpasang saat ini yaitu 250 tempat tidur. Luas tanah 28.000 $\mathrm{m}^{2}$, luas bangunan $17.726 \mathrm{~m}^{2}$ yang terdiri dari instalasi bedah sentral, instalasi laboratorium, instalasi radiologi, instalasi gawat darurat, instalasi farmasi, instalasi gizi dan instalasi kamar jenazah. Sedangkan pelayanan terdiri dari pelayanan rehabilitas medik, pelayanan rawat jalan, pelayanan elektromedik dan pelayanan general check. Selain itu terdapat pemeriksaan unggulan yaitu hemodialisa, bedah tulang dan sendi, pusat diagnostik, perinatal resiko tinggi dan $\mathrm{CT}$ scan. Kemudian terdapat 9 ruang rawat inap (Anggrek, Bougenville, Cempaka, Dahlia, Flamboyan, Kenanga, Mawar, Melati, dan Nusa Indah). Selain itu terdapat juga pelayanan spesialistik yaiu spesialis anak, bedah, penyakit dalam, mata, THT, kulit dan kelamin, kebidanan dan kandungan, jiwa dan syaraf, kantor serta aula.

Penelitian ini dilaksanakan di ruang Dahlia yang terdiri dari dari 10 ruangan yaitu 1 kamar khusus infeksi yang terdiri dari 9 tempat tidur, 2 kamar Kelas II adalah khusus untuk kamar infeksi dan non infeksius masing-masing kamar terdiri dari 4 tempat tidur, 2 kamar Kelas III, yaitu khusus untuk kamar infeksi dan non infeksius masing-masing kamar terdiri dari 4 tempat tidur, 1 ruang (High Nursing Dependent) HND, 1 ruang Isolasi yang terdiri dari 2 tempat tidur, 1 ruang Dokter, 1 ruang Nurse Station, 1 ruang tindakan, 1 ruang obat, dan 1 ruangan khusus untuk bermain. 


\section{Karakteristik responden}

Umur bayi

Berdasarkan tabel 1 dapat diketahui sebagian besar umur bayi yaitu 0-12 bulan sebanyak 25 bayi (96.2\%), umur bayi 13-24 bulan sebanyak 1 bayi $(3,8 \%)$.

\section{Umur ibu}

Berdasarkan tabel 2 diketahui sebagian besar umur ibu 26-35 tahun sebanyak 19 ibu (73.1\%), umur ibu 35-40 tahun sebanyak 7 ibu (26,9\%).

\section{Pendidikan}

Berdasarkan tabel 3, dapat diketahui bahwa 26 orang responden menjadi sampel dalam penelitian ini, paling banyak jumlah respondennya sebanyak 23 orang $(88,4 \%)$ berpendidikan SD, dan yang paling sedikit sebanyak 3 orang $(11,5 \%)$ berpendidikan SMP.

\section{Pekerjaan}

Berdasarkan tabel 4, dapat diketahui bahwa dari 26 responden yang menjadi sampel penelitian ini, dapat dilihat sebagian besar pekerjaan responden adalah wiraswasta sebanyak 8 orang $(30,8 \%)$, pekerjaan petani 7 orang $(26,9)$, pekerjaan buruh 7 orang $(26,9 \%)$, ibu rumah tangga 4 orang $(15,4 \%)$.

\begin{tabular}{ccc}
$\begin{array}{c}\text { Tabel } 1 \text { | Karakteristik responden } \\
\text { Umur bayi } \\
\text { (bulan) }\end{array}$ & Frekuensi & $\begin{array}{c}\text { Perdasarkan umur bayi } \\
\text { Pentase }\end{array}$ \\
\hline $0-12$ & 25 & 96,2 \\
\hline $12-24$ & 1 & 3,8 \\
Total & 26 & 100
\end{tabular}

Tabel 2 | Karakteristik responden berdasarkan umur ibu

\begin{tabular}{|ccc}
$\begin{array}{c}\text { Umur ibu } \\
\text { (tahun) }\end{array}$ & Frekuensi & $\begin{array}{c}\text { Persentase } \\
(\%)\end{array}$ \\
\hline $26-35$ & 19 & 73,1 \\
$35-45$ & 7 & 26,9 \\
Total & 26 & 100
\end{tabular}

Tabel 3 | Karakteristik responden berdasarkan pendidikan

\begin{tabular}{ccc}
$\begin{array}{c}\text { Tingkat } \\
\text { pendidikan }\end{array}$ & Frekuensi & $\begin{array}{c}\text { Persentase } \\
(\%)\end{array}$ \\
\hline SD & 23 & 88,5 \\
SMP & 3 & 11,5 \\
Total & 26 & 100
\end{tabular}

Tabel 4 | Karakteristik responden berdasarkan pekerjaan Pekerjaan Frekuensi Persentase

\begin{tabular}{|c|c|c|}
\hline Buruh & 7 & 26,9 \\
\hline Ibu rumah tangga & 4 & 15,4 \\
\hline Petani & 7 & 26,9 \\
\hline Wiraswasta & 8 & 30,8 \\
Total & 26 & 100 \\
\hline
\end{tabular}

Tabel 5 | Frekuensi pemberian susu formula

\begin{tabular}{ccc} 
Pemberian susu & Frekuensi & Persentase (\%) \\
\hline Tinggi & 14 & 53,8 \\
Rendah & 12 & 46,2 \\
\hline Ta+ I & sc & $1 \mathrm{nn}$
\end{tabular}

Tabel 6 | Frekuensi kejadian diare pada bayi

\begin{tabular}{r|cc} 
Kejadian diare & Frekuensi & Persentase (\%) \\
\hline Diare Akut & 12 & 46,2 \\
Diare kronik & 14 & 53,8 \\
Total & 26 & 100
\end{tabular}

Analisis univariat

Berdasarkan tabel 5 , sebagian besar pemberian susu formula rendah yaitu 14 orang $(53,8 \%)$, dan pemberian susu formula tinggi yaitu 12 orang $(46,2 \%)$.

Berdasarkan tabel 6, sebagian besar diare kronik yaitu 14 orang $(53,8 \%)$, dan diare akut yaitu 12 orang $(46,2 \%)$.

\section{Analisis bivariat}

Berdasarkan tabel 7, pemberian susu formula tinggi dengan kejadian diare akut sebanyak 3 responden (11,5\%), pemberian susu formula tinggi dengan kejadian diare kronik sebanyak 9 responden $(34,6 \%)$, pemberian susu formula rendah dengan kejadian diare akut sebanyak 9 responden $(34,6 \%)$, pemberian susu formula rendah dengan kejadian diare kronik sebanyak 5 responden $(19,2 \%)$.

Hasil uji menggunakan chi square didapatkan nilai $p$ value 0.045 kurang dari $(\alpha=0.05$ ) maka apabila $p$ value $<0,05$, Ho ditolak dan Ha diterima sehingga dapat ditarik kesimpulan bahwa terdapat hubungan pemberian susu formula dengan kejadian diare pada bayi di Ruang Dahlia RSUD Dr.H. Soewondo Kendal. 
Tabel 7 | Analisis bivariat

\begin{tabular}{|c|c|c|c|c|c|c|c|c|}
\hline \multirow{3}{*}{$\begin{array}{l}\text { Pemberian susu } \\
\text { formula }\end{array}$} & \multicolumn{4}{|c|}{ Kejadian diare } & \multirow{2}{*}{\multicolumn{2}{|c|}{ Jumlah }} & \multirow{3}{*}{$x^{2}$} & \multirow{3}{*}{$p$-value } \\
\hline & \multicolumn{2}{|c|}{ Akut } & \multicolumn{2}{|c|}{ Kronik } & & & & \\
\hline & $\mathrm{N}$ & $\%$ & $\mathrm{~N}$ & $\%$ & $\mathrm{~N}$ & $\%$ & & \\
\hline Tinggi & 3 & 11,6 & 9 & 34,6 & 12 & 46,2 & \multirow{3}{*}{4,013} & \multirow{3}{*}{0,045} \\
\hline Rendah & 9 & 34,6 & 5 & 19,2 & 14 & 53,8 & & \\
\hline Total & 12 & 46,2 & 14 & 53,8 & 26 & 100,0 & & \\
\hline
\end{tabular}

\section{Pembahasan}

Hasil penelitian menyatakan bahwa Pemberian susu formula rendah sebanyak 14 responden $(53,8 \%)$, pemberian susu formula tinggi sebanyak 12 responden $(46,2 \%)$. Pemberian susu formula rendah karena pemberian susu kurang sesuai dengan takaran yang sudah di tentukan, bayi minum hanya $10-20 \mathrm{ml}$ dari $60 \mathrm{ml}$ susu dan bayi mengalami intoleransi laktosa selain itu karena ASI ibu yang tidak keluar sehingga bayi terus menerus diberikan susu formula. Pemberian susu formula tinggi karena pemberian susu melebihi takaran yang sudah di tentukan.

Susu formula terkesan lebih baik dari pada ASI, bahkan banyak orang meyakini mitos bahwa susu formula lebih baik dari pada ASI untuk perkembangan otak bayi. Menurut para peneliti, nutrisi dalam ASI sangat penting untuk pertumbuhan otak yang optimal. Seperti rantai pajang asam lemak tak jenuh ganda, yang tidak ada dalam susu formula (Rianti, 2014:59).

Beberapa kondisi ibu membutuhkan penghentian ASI sementara antara lain adalah ibu dengan penyakit berat misalnya menderita sepsis, terkena infeksi virus herpes simplek tipe- 1 dengan lesi di payudara, ibu yang sedang menggunakan obat psiko sedative, antiepilepsi, serta kemoterapi. World Health Organization (WHO) dan United Nation Children's Fund (UNICEF) 2009 juga mencantumkan beberapa kondisi ibu yang bukan kontra indikasi ASI hanya perlu perhatian khusus misalnya ibu dengan hepatitis B pasif dan aktif, hepatitis $C$, tuberculosis, menkonsumsi narkoba, dll (dalam IDAI, 2011:98).

Dari penelitian yang telah di lakukan peneliti memperoleh hasil diketahui sebagian besar umur bayi yaitu 0-12 bulan sebanyak 25 bayi $(96,2 \%)$, umur bayi $13-24$ bulan sebanyak 1 bayi $(3,8 \%)$.
Hasil penelitian yang dilakukan oleh Febry dan Suherna di Balai Agung Sekayu (2009) pemberian susu formula pada bayi dengan usia $<2$ bulan sebanyak 59 (67,9\%), bayi usia 2-5 bulan sebanyak $16(18,4 \%)$, bayi usia $>6$ bulan sebanyak $12(13,8 \%)$.

Berdasarkan penelitian yang telah dilakukan diperoleh data sebagian besar umur ibu 26-35 tahun sebanyak 19 ibu $(73,1 \%)$, umur ibu $35-40$ tahun sebanyak 7 ibu $(26,9 \%)$. Hasil data dari karakteristik responden sesuai tingkat pendidikan bahwa 26 orang responden yang menjadi sampel dalam penelitian ini, sebanyak 23 orang $(88,4 \%)$ berpendidikan SD, dan yang paling sedikit sebanyak 3 orang $(11,5 \%)$ berpendidikan SMP. Sedangkan data berdasarkan pekerjaan responden adalah wiraswasta sebanyak 8 orang $(30,8 \%)$, pekerjaan petani 7 orang $(26,9)$, pekerjaan buruh 7 orang $(26,9 \%)$, ibu rumah tangga 4 orang $(15,4 \%)$. Pemberian susu formula rendah sebanyak 14 responden $(53,8 \%)$ karena faktor ibu bekerja dan bayi tidak mau minum susu, pemberian susu formula tinggi sebanyak 12 responden $(46,2 \%)$ karena faktor dari ASI ibu yang tidak keluar dan ibu bekerja, sehingga melebihi takaran dan frekuensi yang sudah ditentukan oleh ahli gizi.

Kejadian diare pada bayi di Ruang Dahlia RSUD Dr.H. Soewondo Kendal sebagian besar diare kronik yaitu 14 orang $(53,8 \%)$, dan diare akut yaitu 12 orang $(46,2 \%)$.

Berdasarkan data hasil penelitian yang dilakukan oleh Febry dan Suherna di Balai Agung Sekayu (2009) ada hubungan pemberian susu formula dengan kejadian diare. Kejadian diare sebanyak 46 (52\%) berbeda dengan penelitian yang di lakukan oleh Fauziah (2014) di (Bidan Praktik Mandiri) BPM Sri Rahayu menunjukkan bahwa responden yang diberi susu formula dan mengalami diare sebanyak 8 responden $(28,6 \%)$. 
Penelitian yang di lakukan oleh Annalisa Passariello, dkk (2010), di Neonatal Intensive Care Unit (NICU) of Urban Children's Hospitals menyebutkan bahwa tiga puluh sembilan kasus diare (36 akut, 3 kronis) diidentifikasi. Tingkat kejadian diare adalah 6,72 per 1000 bayi yang dirawat di rumah sakit. Etiologi didefinisikan pada 29 dari 39 bayi (74,3\%), alergi makanan (20,5\%),Diare tergolong akut pada 36 pasien $(92,3 \%)$ dan kronis pada 3 neonatus $(7,7 \%)$, diagnosis alergi susu sapi (CMA) dilaporkan terjadi pada 8 kasus. Lima dari kasus ini dianggap berisiko terhadap penyakit alergi susu sapi.

Berbeda dengan penelitian yang telah dilakukan didapatkan hasildiare kronik yaitu 14 orang $(53,8 \%)$, diare kronik terjadi karena bayi diberikan susu formula melebihi frekuensi dan takaran yang sudah di tentukan ahli gizi, selain itu karena faktor dari ASI ibu yang tidak keluar, dan ibu sering mengganti susu formula dan diare akut yaitu 12 orang $(46,2 \%)$, diare akut terjadi karena bayi mengalami intoleransi laktosa.

Berdasarkan analisa bivariat Pemberian Susu Formula (kategori tinggi dan rendah) dengan kejadian diare (kategori diare akut dan diare kronik). Hasil uji chi square dapat diketahui bahwa nilai chi square hitung besar $4.013>3,841$ dan $p$ value 0,045 yang berarti $<0,05 \alpha=0,05$ ( $p$ value $<$ $\alpha)$ atau 0,045<0,05 maka $\mathrm{H}_{0}$ ditolak dan $\mathrm{H}_{\mathrm{a}}$ diterima. Sehingga ada hubungan yang signifikan pemberian susu formula dengan kejadian diare pada bayi di Ruang Dahlia RSUD Dr.H.Soewondo Kendal.

\section{Kesimpulan}

Berdasarkan tujuan penelitian yang ditemukan, maka hasil penelitian mengenai hubungan pemberian susu formula dengan kejadian diare pada bayi Di Ruang Dahlia RSUD Dr.H.Soewondo Kendal dapat disimpulkan bahwa:

1. Sebagian besar responden pemberian susu formula rendah sebanyak 14 responden $(53,8 \%)$.

2. Sebagian besar responden kejadian diare kronik 14 responden $(53,8 \%)$.

3. Terdapat hubungan yang signifikan antara pemberian susu formula dengan kejadian diare pada bayi di Ruang Dahlia RSUD Dr.H. Soewondo Kendal ( $p$ value 0,045 atau $p$ value $<0,05)$.

Diharapkan dapat mencetak generasi penerus yang dapat mengembangkan dan memberi informasi atau masukan bagi dunia keperawatan dan penelitian yang lain tentang pemberian susu formula dengan kejadian diare di Ruang Dahlia RSUD Dr.H. Soewondo Kendal.

\section{Bibliografi}

1. Annalisa Passariello, dkk. (2010). Diarrhea Neonatal Intensive Care Unit (NICU) of Urban Children's Hospitals.

2. Axton dan Fugate. (2014). Rencana Asuhan Keperawatan Pediatrik edisi 3. Jakarta: EGC.

3. Dinas Kesehatan Provinsi Jawa Tengah. (2015). Buku Profil Kesehatan Provinsi Jawa Tengah Tahun 2015.

4. Febry dan Suherna. (2009). Hubungan Antara Pemberian Susu Formula Dengan Kejadian Diare Pada Anak Usia 0-24 Bulan di Wilayah Kerja Puskesmas Balai Agung Sekayu.

5. IDAI. (2011). Buku Ajar Nutrisi Pediatrik dan Penyakit Metabolik. Jakarta.: Badan Penerbit IDAI.

6. Kalay. (2012). Hubungan Antara Tindakan Pemberian Susu Formula Dengan Kejadian Diare Pada Bayi Usia 0-6 Bulan di wilayah Kerja Puskesmas Ranotana Weru Kota Manado.

7. Kementrian Kesehatan Republik Indonesia. (2014). Profil Kesehatan Indonesia Tahun 2014.

8. Notoadmodjo. (2012). Metodologi Penelitian Kesehatan. Jakarta: Rineka Cipta.

9. Prihaningtyas. (2014). Deteksi dan Cepat Obati 30+ Penyakit yang Sering Menyerang Anak. Yogyakarta: Media Pressindo.

10. Purwandari, dkk. (2014). Perkembangan Balita : Deteksi Dini Stimulasi Tumbuh Kembang Balita. Yogyakarta: IKAPI.

11. Riyanti. (2014). Mitos-Mitos dan Fakta-Fakta Seputar ASI. Jogyakarta: Flash Books.

12. Suharyono. (2012). Diare Akut Klinik Dan Laboratorium. Jakarta: Rineka Cipta. 